\title{
Professional Satisfaction as a Key Factor in Employee Retention: A case of the Service Sector
}

\author{
Yeliz PEKERŞEN \\ Faculty of Tourism, Necmettin Erbakan University, Turkey \\ Onur TUGAY \\ Necmettin Erbakan University, Turkey
}

Received: 28 November 2019. Revision received: 14 February 2020. Accepted: 17 February 2020.

\begin{abstract}
The aim of this study is to determine the relationship between the reasons for workers employed in catering and kitchen departments leaving their jobs and their job satisfaction. In accordance with this purpose, data were collected by a convenience sampling method with 244 employees between 10.04.2019-24.04.2019 including food and beverage and kitchen departments in the three, four, and fivestar hotels operating in Eskişehir. According to the data obtained, it is concluded that the majority of the hotel employees consider the fact that the wages paid in the enterprises are not satisfactory and that there is not a significant relationship between the reasons for hotel employees' ceasing of employment and their occupational satisfaction levels. It can be stated that employees have a great role in increasing the rate of profit, which is the main purpose of the hotel enterprises, to run the business smoothly, and to ensure customer satisfaction and loyalty. Therefore, it is an important issue to focus on meeting the professional satisfaction levels of the employees and determining the possible factors that may lead to ceasing employment.
\end{abstract}

Key Words: Ceasing of employment, occupational satisfaction, hotel staff, tourism.

JEL Classification: Z31, J28.

Reference: Pekerşen, Y., Tugay, O (2020). Professional Satisfaction as a Key Factor in Employee Retention: A case of the Service Sector. Journal of Tourism and Services, 20(11), 1-27. doi: 10.29036/jots.v11i20.123

\section{Introduction}

Since individuals spend most of their daily lives in their workplaces, their jobs and the business they work for are an important part of their lives. Therefore, the relationship between employee health and work life is in constant interaction with each other (Öztürk, et al., 2008: 93). The success of hotel enterprises depends on financial and external factors as well as efficient staff. Enterprises that increase personnel productivity and provide motivation achieve their goals in the short term (Erdem, 2004: 51; Szczepańska-Woszczyna, 2018: 36). The satisfaction of employees affects both business and personal lives positively. Therefore, it is important to create motivated employees who have adopted the vision of the company and who have high loyalty to their jobs and workplace (Örücü \& Esenkal, 2005: 36). In order to achieve the targets determined by the enterprises, it is necessary to meet the expectations of the employees from their jobs and increase their occupational satisfaction levels (Gavcar \& Topaloğlu, 2008: $60)$. 


\section{JOURNAL OF TOURISM AND SERVICES}

Issue 20, volume 11, ISSN 1804-5650(Online)

www.jots.cz

The satisfaction of the employees and quality of services, the sector not providing much opportunity for mechanization and the service being realized by communicating directly with customers by employees are of extra importance for hotel enterprises (İnce, 2008: 58; Türkay, Korkutata ve Y1lmaz, 2018: 15). In this context Belas et al. (2014) emphasize the effect of satisfaction mirror in service sector. It means that customer satisfaction is determined by satisfaction of employees.

The direct contact of the guests with the hotel employees is related to the increase in the quality, trust, brand value, profit rate and reputation offered by the company (Yilmaz \& Sezgin, 2017: 167). Therefore, the managers of food and beverage and kitchen departments in hotel enterprises should show the sensitivity required to provide the factors that increase the level of satisfaction such as qualifying staff, improving their performance and providing continuity in the work (Ince, 2015: 26). Otherwise, the cost of personnel selection, training and orientation processes will put enterprises in financially difficult situations (Çakınberk et al., 2011:268).

The main factors affecting the employees' ceasing of employment in the hotel sector are wage level, long working hours, quality of work, occupational satisfaction level, inadequate working environment, lack of promotion opportunities, injustice experienced in the working environment, presence of unethical behaviors, sexual harassment, conflict, management style. Occupational satisfaction plays an important role in the hotel industry. The efficiency of the work performed, the quality of the service provided and the loyalty of the personnel to the enterprise depend on the high level of satisfaction of the employees. While achieving the occupational satisfaction of the employees ensures that they work efficiently in line with the vision of the enterprise, the employees with low occupational satisfaction experience inefficiency in their jobs, causing the employees remaining in the organization to work with more workload and creating a problem of filling the employment gap created by the missing personnel in the enterprise.

The aim of this study is to understand the relationship between the reasons for ceasing of employment and occupational satisfaction of the employees of the food and beverage and kitchen department employed in hotel enterprises and to determine the reasons for hotel employees' ceasing of employment. Employees who have gained their business skills and who fulfill their business requirements are especially important in terms of customer satisfaction and financial gains especially for the hotel enterprises where the service is provided directly. The employees who perform well increase the profit, image and product and service quality of the enterprises. In terms of hotel enterprises, this depends on the satisfaction of the employees in their jobs, that is, the achievement of occupational satisfaction. In hotel enterprises where staff turnover rate is high, the loss of efficient employees can create many problems especially for the kitchen department where cooperation is important. Factors such as the cost of start and end of employment for the enterprise, filling the vacant hotel staff, training of new personnel, and adaptation require both time and budget. In this context, it is thought that the hotel enterprise managers should be directed in terms the importance of occupational satisfaction levels of the employees and which factors cause them to cease their employments and therefore prevent it and to address to the distress of catering-kitchen department employees.

\section{Literature Review}

\subsection{The Concept of Ceasing of Employment}

Ceasing of employment means that employees leave the enterprise and organization and continue to work with another organization (Kaya \& Abdioğlu, 2010: 130). Ceasing of employment is also affected by the level of occupational satisfaction that increases or decreases individuals' commitment to the enterprise they work for. It is the result of the decision made by the employees if they are dissatisfied due to certain conditions in their work and do not reach the level of occupational satisfaction (Rusbult et al., 1988: 614). 


\section{JOURNAL OF TOURISM AND SERVICES}

Issue 20, volume 11, ISSN 1804-5650(Online)

www.jots.cz

\subsection{Reasons for Ceasing of Employment in Hotels}

'The individuals' reasons for ceasing of employment mostly depend on factors such as wages, hours, shifts, working conditions, management, colleagues, job security, quality of work, use of skills and abilities, career opportunities, policies and rules, new job opportunities, loss of seniority or job offers (Bon \& Forbringer, 1992: 49). Particularly, accommodation industry employees can leave their jobs to get employed in better working conditions due to wage levels, working hours, lack of time for social life and career opportunities (Brown et al., 2015: 134).

Wage: It is an important determinant of the continuation of the work of the employees and the decisions to stay in the enterprise. The amount of wages received by employees affects their departure from the enterprise they work for (Barutçugil, 2004: 110). Employees, who define wage as the equivalent of their labor and contributions to the enterprise, may feel that they are not valuable as a result of low wages (Berg \& Frost, 2005: 668). Considering that wages affect both the decision to leave and the level of occupational satisfaction of the employees, the remuneration system in hotels is effective for encouraging employees, increasing their loyalty to the company, providing motivation and achieving productive job performance from employees (Kline \& Hsieh, 2007: 70).

Promotion prospects: The promotion of employees to a higher position in terms of authority, responsibility and wage is called promotion. When the individuals working in the same position for a long time do not get promotion, their commitment to the enterprise decreases (Yalçın \& İplik, 2007: 494; Androniceanu, 2019). Employees expect a career in which they are rewarded by organizations. Organizational rewards include promotion, bonuses and the desired task assignments (Taormina \& Law, 2000: 92). The status of the promoted individuals increases not only their wages but also their high productivity. This also provides credibility for the employee. Therefore, it is desirable for employees to be promoted in their jobs (Erdoğan, 1994: 378). The employee is promoted as a result of bringing him to a higher level, which requires more responsibility than the level of work that he has done, and gives him more wages, privilege and freedom of authority (Bingöl, 2003: 425). The lack of promotion opportunities in the hotel sector leads to the separation of trained personnel. Therefore, management should provide career and promotion opportunities for employees (Çakınberk et al., 2011: 270).

Discrimination Between Employees: Discrimination in working life is expressed as the fact that people with similar education, talent, experience come short compared to other employees because of their demographic characteristics such as being a woman or a minority in terms of benefiting from opportunities such as promotion and wages (Free and Reporting, 2002: 159; Mura et al., 2019). Wilkinson et al. (2019) searched this important issue focusing on the automation shape talent attraction and retention. Discrimination can occur in many aspects such as remuneration, working time, break, leave, performance evaluation, promotion, vocational training (Seymen \& Bolat, 2005: 35). Discrimination can have negative effects and consequences for employees (Baybora, 2010: 54) and affect the production levels and productivity of the employees negatively and may cause qualified employees to cease the employment (Demirel, 2011: 67).

Physical Working Conditions: The efficiency of the personnel working in the hotel sector is affected by the working environment and the physical conditions that make up this environment. Improvement of working conditions leads the staff to work more productively and efficiently (Sabuncuoglu, 1994: 94). Employees in sectors providing food and beverage services must act quickly in the working environment. The fact that the conditions in the working environment meet the expectations of the employees affects the satisfaction of the employees positively and this situation is also reflected in their occupational satisfaction (Pelit et al., 2011: 794; Ciobanu et al., 2019).

Stress: Work stress is expressed as the physical and emotional reactions of the individual to the characteristics of the threatening work environment as a result of the relationship between the worker and the work environment (Hu \& Cheng, 2010: 1138). Stressful situations arising from employee relations, work itself or working conditions become a negative factor for hotel employees. Stress experienced in hotel enterprises can also cause physiological disorders for employees (Çivilidağ, 2014: 3). 


\section{JOURNAL OF TOURISM AND SERVICES}

Issue 20, volume 11, ISSN 1804-5650(Online)

www.jots.cz

Long working hours, low wage policies and layoffs cause employees to experience work stress (Genç et al. 2016: 98). Work-related stress directly affects the work done by working people (Aydin, 2004: 7). The fear of confronting the work environment depending on the stress experienced may lead the employee to negative behaviors towards his/her job. As a result, the obligation to go to work is an important cause of tension and anxiety (Aydin, 2002: 75; Bacik et al., 2019; Ibrahim, 2019). Anxious staff is more likely to have an accident. Factors such as careless behavior, not being aware of the danger, fear cause accident risk (Şimşek \& King1r, 2006: 208). At the same time, the stress of the employees affects the colleagues and causes negative results in business performance and success (Gümüştekin \& Öztemiz, 2005: 282). This leads to a serious decrease in the productivity and occupational satisfaction levels of the employees, the absence of work and ceasing of employment (Aydin, 2002: 106).

Working Hours: Individuals employed in the hotel industry generally work for very long hours (McNamara et al., 2011: 226). Due to this, hotel employees have physical health problems in the long term (Bohlea et al., 2004: 23). The length of the hours worked significantly affects the physical, psychological and emotional states of the employees. The irregularity of shift hours, weekend and night work in the hotel sector causes employees to face problems such as inability to allocate time to their families (Birdir \& Tepeci, 2003: 93). Conflicts between work and family create emotional exhaustion for employees, which can leave employees (Cleveland et al., 2007: 277).

Job Security: Job insecurity is defined as the factors that threaten the continuity of the job, threaten the continuity of the job and concern about the loss of the job (Erlinghagen, 2008: 183). Anxiety of employees to lose their jobs may arise as a result of various threats to business continuity such as economic crisis, shrinkage of the enterprise (Seçer, 2011: 46). In the short term, job insecurity has an impact on factors such as occupational satisfaction, job loyalty, attitudes and trust. In the long term, it causes the physical and psychological health of the employees to deteriorate, poor performance in terms of work and undesirable situations related to leaving the enterprise (Sverke et al., 2005: 38; KotRadojewska \& Timenko, 2018). The motivation, occupational satisfaction and loyalty of the employees who think that they have job security are high (Bakan \& Büyükbeşe, 2004: 55). Even the possibility of job insecurity as it causes economic problems affects the employees (Hellgren et al., 1999: 181).

Incentives and Rewarding: Incentives and rewards are among the factors that improve the performance of employees in their jobs. A fair incentive and rewarding program has features that enhance employee loyalty and occupational satisfaction (Gaertner, 1999: 489). It adds value to personal and organizational performances by increasing employee satisfaction (Kontoghiorghes, 2001: 47). Thanks to the rewards, it is ensured that employees and employees make sense of the business and work in line with the business objectives (Bulut \& Çavuş, 2015: 608).

Abuse: While female employees feel worthless due to the fact that they are mostly employed in lower levels in the hotel sector, that they are expected have close communication increases sexual harassment behavior (Gilbert et al., 1998: 49). Sexual harassment can take place not only physically but also with disturbing words or behavior. Verbal harassment that occurs from the strong to weak can also be caused by emotionally disturbing actions such as psychological pressure (Pryor \& Day, 1988: 415). Sexual harassment may cause negative consequences for harasser, harassed, organizational structure and communication (Aguinis et al., 2001: 207). Employees who have been subjected to harassment leave their jobs in order to avoid a similar situation, and even if they continue, they cannot be productive in their jobs after the negative situation (Mimaroğlu \& Özgen, 2008: 331). It causes traumatic conditions such as anxiety, stress, depression and anger in employees (Solmuş, 2005: 2). Accordingly, it affects the decision of employees to continue or not to work (Barling et al., 2003: 277).

Organizational Justice and Ethics: Organizational justice is a system that brings the right personnel to the organization for the enterprise, increases the loyalty of the employees to the organization, encourages them to be more productive and fair perception by the employees (Fay \& Thompson, 2001: 222). When employees face unfair situations in the working environment, they are more likely to leave the organization (Hang-Yue et al., 2011: 1208). Unethical behaviors are expressed as discrimination- 


\section{JOURNAL OF TOURISM AND SERVICES}

Issue 20, volume 11, ISSN 1804-5650(Online)

www.jots.cz

favoritism, intimidation, neglect, corruption-bribery, humiliation, oppression-violence, sexual harassment, gossip, abuse of duty among employees (Şimşek \& King1r, 2006: 264). In addition, unethical behaviors may occur while performing the work (Knouse \& Giacalone, 1992: 371). Unethical behavior can lead to insecurity. Meanwhile, insecurity can lead to deterioration of relations in the working environment, loss of organizational work, communication disruptions, loss of commitment and ceasing of employment (Şenturan, 2014: 108).

Conflict: It occurs between the employees or the employee and the enterprise and causes the workflow to halt or stop completely in the enterprise (Eren, 2003: 609). It creates a loss of productivity and motivated employees and endangers the existence of the organization (Solmuş, 2004: 40). The factors that cause conflict may stem from organizational structure, participation in management and decisions, inequality in rewarding, lack of job descriptions and responsibilities, subordinate-superior relationship, differences in management style and problems arising from job sharing (Aktaş \& Kıllnç, 2007: 78). Conflict creates destructive consequences such as breakage of communication within the organization, decrease of loyalty, damage of cooperation, hostility of employees and decrease in job satisfaction (Üngüren, 2008: 885).

\subsection{Concept of Occupational Satisfaction}

Occupational satisfaction is the positive emotional state the employee feels as a result of his/her pleasure or work received from his/her job as a result of his/her evaluation of the qualifications and work life of his/her job (Başaran, 2000: 215). Factors such as employee's appreciation, pleasure, and meaningfulness increase the level of occupational satisfaction (Yeh, 2013: 220). While the employees with high occupational satisfaction are diligent in fulfilling their responsibilities, the unfulfilled employees are distressed, unhappy and tense (Heller et al., 2002: 816; Vveinhardt, \& Gulbovaite, 2018: 548-549). Occupational satisfaction is the result of the interaction between the employee and his/her job. Therefore, participation in work affects organizational performance, productivity and continuity (Dienhart \& Gregoire, 1993: 30). High occupational satisfaction provides benefits that prevent employees from quitting and strengthen organizational commitment (Yang, 2010: 611).

\subsection{Factors Affecting Occupational Satisfaction}

Occupational satisfaction arises due to many factors (Aş1k, 2010: 31). These factors are divided into two groups: individual and organizational. Individual factors are internal and organizational factors are external (Lee \& Way, 2010: 345). Occupational satisfaction increases or decreases according to internal and external factors that determine employee behaviors. The perception of these factors by working individuals and the way they affect the job they perform constitute the occupational satisfaction levels (Frye \& Mount, 2007: 110). The level of occupational satisfaction varies depending on the working style and conditions, organizational climate, demographic characteristics and career expectations (Tütüncü \& Kozak, 2007: 4). In addition, factors such as the quality of work, wages and additional income, job security, promotion, fair rewarding, management style affect occupational satisfaction (Bakan \& Büyükbeşe, 2007: 7).

\section{Individual Factors}

Occupational satisfaction varies from person to person (Lopopolo, 2002: 984). As the education level of individuals increases, the level of job satisfaction decreases. Employees with high levels of education want to gain gains that will provide both financial and psychological satisfaction such as increase in wages, prestige, authority and supervision (Eskildsen et al., 2004: 122). High levels of education can lead to dissatisfaction by generating unfulfilled expectations (Wharton et al., 2000: 69). Depending on the status and experience, the level of occupational satisfaction increases. Employees who have experience in high positions and jobs are satisfied with their jobs compared to low-ranking and 


\section{JOURNAL OF TOURISM AND SERVICES}

Issue 20, volume 11, ISSN 1804-5650(Online)

www.jots.cz

inexperienced employees (Oshakbemi, 2000: 1212). The age of the individuals also affects their level of satisfaction. This is caused by the needs of individuals, maturation process and age-changing cognitive structures (Rhodes, 1983: 340). Satisfaction level also varies according to employees' personal success, perceived self-efficacy, performance levels and beliefs about their ability to produce (Judge et al., 2007: 108).

\section{Organizational Factors}

Conditioning and occupational satisfaction of employees is important in the labor-intensive hotel sector (Zhang et al., 1999: 49). Providing occupational satisfaction depends on finding the right ratio between the qualifications of the job and the expectations of the employees (Tütüncü \& Kozak, 2007: 4). As a result of their needs and experiences, employees have expectations (Aziri, 2011: 78). Supporting factors such as awards, bonuses, premiums received by employees based on their performance increase the level of satisfaction. This also enables employees to perform effectively to meet their expectations (Lawler \& Porter, 1967: 23). The harmony between the expectations of the employees and the benefits provided by their work increases their occupational satisfaction (Kuzgun et al., 1999: 15). Failure to meet the expectations of the employees may lead to dissatisfaction with their jobs, leaving them out of the business and even leaving the sector (Cleveland et al., 2007: 280). Highly satisfied employees do not think about leaving because they are satisfied with their job (Lawler \& Porter, 1967: 22).

The communication style and behaviors of the managers may affect the occupational satisfaction of the employees positively or negatively. Employees who communicate with executives in a healthy manner are willing and satisfied with the work environment (Kumari \& Pandey, 2011: 224). At the same time, intra-organizational communication and relations, organization support is especially important for labor intensive services that require cooperation (Pan, 2015: 86). Factors such as fair leadership, a good organizational climate, role clarity, and participation in decisions to be taken significantly decrease the production loss levels of employees, while inequalities cause a significant high production loss (Felicita, 2016: 97).

The long hours worked reduce the level of occupational satisfaction. However, the application of a fair remuneration and reward system, and knowing that the employee will be given what he deserves, prevents the reduction of professional satisfaction (Groot \& Brink, 1999, 359). Working conditions also affect the level of satisfaction (Lee-Ross, 1998: 68; Horváth \& Hollósy, 2019). When employees do not have the appropriate working environment and sufficient equipment to fulfill their job responsibilities, they cease employment (Biggs et al., 2011: 145). Working conditions affect the satisfaction of the organization as well as affect the professional job satisfaction (Saari \& Judge, 2004: 397). Employees with a sense of occupational safety feel that they are given importance, and use their skills in the way that their professional development allows. This positively affects saturation levels (Dienhard \& Gregoire, 2016: 31). The level of occupational satisfaction increases depending on the length of employment (Zhang et al., 1999: 50). Satisfaction levels of long-term individuals are increased by obtaining professional gains such as seniority, promotion, wage increase and status (Cruz et al., 2014: 67).

\subsection{The Relationship Between Reasons for Cof Employment and Job Satisfaction}

There is a significant relationship between job satisfaction and ceasing of employment. Those who experience occupational dissatisfaction are considering ceasing of employment job at the first opportunity (Başaran, 2000: 222). Low level of occupational satisfaction, slow operation of the job, loss of success and productivity, loss of commitment, the occurrence of work accidents increase the complaints about the work causes (Akınc1, 2002: 7). The employee, who has low level of satisfaction, seeks ways to quit and move to another job when he/she finds the opportunity to escape from work. This harms the enterprise (Özkalp, 2015: 80). Ceasing of employment leads to disruption of work, depresses the remaining business employees, creates cost problems such as finding and training the staff to replace the employee (Türk, 2007: 98). 


\section{JOURNAL OF TOURISM AND SERVICES}

Issue 20, volume 11, ISSN 1804-5650(Online)

www.jots.cz

Employees with low level of satisfaction are unhappy, they are not satisfied with being in the workplace and the job they do, so they do not want to remain responsible for the job when possible (Aş1k, 2010: 46). Employees experiencing dissatisfaction also suffer from psychological and physical aspects, and they look pessimistic in business life (Koyuncu \& Sevin, 2017: 36). Considering the effects of occupational satisfaction on working life, it is observed that it significantly affects the ceasing of employment (Kumari \& Pandey, 2011: 225).

\section{Methodology}

\subsection{The Purpose and Importance of the Research}

The aim of this study is to determine the relationship between the reasons of workers employed in catering and kitchen departments leaving their jobs and their job satisfaction. Particularly, the increasing number of resignations in the service sector may cause the hotel enterprises to face big problems in terms of labor management. Therefore, it is important to know the expectations of the employees, to reveal the reasons for leaving the job, to determine what can be done in order not to quit their jobs and to increase their occupational satisfaction levels. In this way, policies will be developed to recruit efficient employees and to reduce their turnover. The research has sought the answers to the questions of "What are the occupational satisfaction levels of hotel employees?", "Is there a relationship between the reasons for hotel employees' ceasing of employment and occupational satisfaction levels?" and "What are the possible reasons that may cause the hotel employees to cease their employment?". In addition, in line with the aim of the study and based on the literature (Giritlioğlu ve Özlü, 2016, Kim ve Jogaratnam, 2010, Choi, 2006, Lam et al., 2001) the following research hypotheses have been developed to investigate the relationship between the reasons employees to cease the employment and job satisfaction;

$\mathrm{H}_{1}$ : There is a significant relationship between reasons of hotel employees' for ceasing of employment and occupational satisfaction levels.

$\mathrm{H}_{2:}$ Reasons for hotel employees' ceasing of employment affect their occupational satisfaction.

\subsection{Population and Sample of the Research}

The population of the research consists of employees of food and beverage and kitchen departments working in three, four- and five-star hotels in Eskişehir who have obtained tourism operation certificate from the Ministry of Culture and Tourism. According to the statistics of the Ministry of Culture and Tourism (2019), there are 24 three, four- and five-star hotels with tourism operation certificate in Eskişehir. Within the scope of the research, all three, four- and five-star hotels in Eskişehir have been contacted; for the application phase of the research, a questionnaire has been applied by receiving positive answers from 22 hotel enterprises. 3 of the hotel enterprises participating in the study are five-star, 5 of them are 4-star and the remaining 14 are three-star hotel enterprises. The reason why three-, four- and five-star hotels have been preferred in the research is the size of the organizational structure and the large number of personnel compared to other hotels. The reason for investigating the food, beverage and kitchen department employees is the idea that long working hours and heavy working conditions may be a factor in the reasons for leaving the employees and that the conditions of the sector may affect the occupational satisfaction of the personnel. In order to determine the number of employees in the population, the managers of the Human Resources Department of the 22 hotels where the study is conducted have been asked for the number of personnel in the kitchen and catering departments. According to the information obtained, approximately 110 kitchen workers and 176 food and beverage employees are employed in these hotels. However, the managers of the Human Resources Department of some of the interviewed hotels have stated that this number varies depending on the business situation 


\section{JOURNAL OF TOURISM AND SERVICES}

Issue 20, volume 11, ISSN 1804-5650(Online)

www.jots.cz

and intensity and therefore they cannot give a clear figure. In this respect, a questionnaire has been distributed to all employees who accepted to fill the questionnaire easily. In total, 286 questionnaires have been distributed and feedback is provided from 266 questionnaires. However, 22 of these surveys have not been included in the analysis process due to the fact that not all of the questions have been answered and there have been marking errors. The total number of surveys included in the analysis process is 244 .

\subsection{Data Collection Method and Analysis}

Survey technique has been used to collect data about the research. The data has been collected between 10.04.2019-29.04.2019. In this study, the questionnaire form used by Çanakç1 (2018) in his doctoral thesis study is used. The questionnaire consists of two parts. The first part consists of questions that have been designed to determine the demographic characteristics of the participants. In the second part, there are 24 statements which aim to determine the reasons of the employees' resignation. In order to measure the occupational satisfaction levels of the employees, the questionnaire form used by Yildırım (2018) in his master's thesis has been used. This questionnaire consists of 20 statements in order to determine the satisfaction of employees from their professions. They are asked to evaluate the statements within the scale of employees' reasons to cease the employment and occupational satisfaction as; 1 : strongly disagree, 2: disagree, 3: neither agree nor disagree, 4: agree, 5: strongly agree.The 4th, 9th, 10th, 11th, 14th and 19th items in the occupational satisfaction scale have been reverse coded. The arithmetic means of the statements have been evaluated and interpreted using the ranges given below (Demirel, 2014: 235);

- $1.00 \leq \mathrm{x}^{-}<1.80$ (Very low)

- $1.81 \leq \mathrm{x}<2.60$ (Low)

- $2.61 \leq \overline{\mathrm{x}}<3.40$ (Medium)

- $3.41 \leq \mathrm{x}<4.20$ (High)

- $4.21 \leq \overline{\mathrm{x}}<5.00$ (Very high)

The data collected within the scope of the research has been analyzed using SPSS 22.0 statistical package program. Firstly, it has been checked whether incorrect data has been entered. In order to determine whether to use parametric or non-parametric tests, normality test has been performed and skewness-kurtosis values have been examined. George and Mallery (2003: 99) state that the distribution can be considered normal when skewness and kurtosis values are between -2 and +2 . As a result of the analysis, it is observed that the kurtosis and skewness values of the statements in the scales are between -2 and +2 . Therefore, parametric tests have been used in the analysis of the data. The reliability analysis of the scales has been made and the Cronbach's Alpha coefficient of the reasons for leaving the job scale has been found to be 0.989 and the Cronbach's Alpha coefficient of the occupational satisfaction level has been found to be 0.672. These values show that the scales are reliable (Kay1ş, 2010: 405). The data obtained from the analysis have been tested with percentage, frequency analysis, factor analysis, correlation and simple linear regression analysis.

\section{Findings}

Data on the demographic characteristics of the participants are shown in Table 1. Accordingly, $203(83.2 \%)$ of the hotel employees are male and $41(18.2 \%)$ are female. When age ranges are examined, $97(39.8 \%)$ are in the 18-24 age range, $99(40.6 \%)$ are in the 25-34 age range, $15(6.1 \%)$ are in the 35-44 age range, 33 ' Fifty years of age (13.5\%) are over 45 years old. While $146(59.8 \%)$ of the participants are single, $98(40.2 \%)$ are married. $105(43.0 \%)$ of the participants are high school graduates, $94(38.5 \%)$ are associate degree graduates, $40(16.4 \%)$ are undergraduate and $5(2.0 \%)$ are graduate. employees. 228 


\section{JOURNAL OF TOURISM AND SERVICES}

Issue 20, volume 11, ISSN 1804-5650(Online)

www.jots.cz

(93.4\%) of the hotel employees participating in the questionnaire has stated that they have received vocational training, while $16(6.6 \%)$ stated that they have not receive vocational training. When the total working years of the participants have been examined in the tourism sector, it is observed that 5 of them $(2.0 \%)$ has worked for less than one year, $127(52.0 \%)$ between 1 and 5 years, $43(17.6 \%)$ between 6 and 10 years, $26(10.7 \%)$ between 11 and 15 years and $43(17.6 \%)$ for 16 years and more. When the age of start of employment for the hotel employees is taken into consideration, $9(3.7 \%)$ are under 18 years old, $228(93.4 \%)$ are between $18-24$ years old and $7(2.9 \%)$ are 25 years or older when they have entered the sector.

Table 1. Socio-Demographic Characteristics of Participants

\begin{tabular}{|c|c|c|}
\hline Gender & $\mathrm{n}$ & $\%$ \\
\hline Male & 203 & 83.2 \\
\hline Female & 41 & 16.8 \\
\hline \multicolumn{3}{|l|}{ Age } \\
\hline $18-24$ years old & 97 & 39.8 \\
\hline $25-34$ years old & 99 & 40.6 \\
\hline $35-44$ years old & 15 & 6.1 \\
\hline 45 years and older & 33 & 13.5 \\
\hline \multicolumn{3}{|l|}{ Marital Status } \\
\hline Single & 146 & 59.8 \\
\hline Married & 98 & 40.2 \\
\hline \multicolumn{3}{|l|}{ Educational Status } \\
\hline High School & 105 & 43.0 \\
\hline Associate & 94 & 38.5 \\
\hline Undergraduate & 40 & 16.4 \\
\hline Postgraduate & 5 & 2.0 \\
\hline \multicolumn{3}{|c|}{ Whether S/he Received Training Related to His Profession } \\
\hline Yes & 228 & 93.4 \\
\hline No & 16 & 6.6 \\
\hline \multicolumn{3}{|c|}{ How Long S/he Has Worked in the Tourism Sector } \\
\hline Less than 1 year & 5 & 2.0 \\
\hline $1-5$ years & 127 & 52.0 \\
\hline $6-10$ years & 43 & 17.6 \\
\hline $11-15$ years & 26 & 10.7 \\
\hline 16 years and over & 43 & 17.6 \\
\hline \multicolumn{3}{|c|}{ Age of Entry to the Sector } \\
\hline Under 18 years old & 9 & 3.7 \\
\hline $18-24$ years old & 228 & 93.4 \\
\hline 25 years and older & 7 & 2.9 \\
\hline Total & 244 & 100 \\
\hline
\end{tabular}

\subsection{Participants' Views on the Difficulties of Working in the Tourism Sector}

Table 2 presents the frequency and percentage distributions of the participants' views on the good aspects of the study in the tourism sector. For the best part of working in the sector, 41 people $(16.8 \%)$ have responded as doing their favorite job, 25 people $(10.2 \%)$ as having a satisfactory salary, 24 people $(9.8 \%)$ as receiving double wages on special days, 23 people (\%) 9.4) as it being a job requiring labor and care and 20 people $(8.2 \%)$ as appreciation/occupational satisfaction of the product.

Table 3 exhibits the frequency and percentage distributions of the participants' views on the difficult aspects of working in the tourism sector. For the hardest part of working in the sector, 21 people $(8.6 \%)$ have responded as lack of social life, 21 people $(8.6 \%)$ as working hours and leave days changing frequently, 20 people $(8.2 \%)$ as not being able to allocate time to family, 19 people $(7.8 \%)$ as working on 


\section{JOURNAL OF TOURISM AND SERVICES}

Issue 20, volume 11, ISSN 1804-5650(Online)

www.jots.cz

public holidays and holiday celebrations and 19 people $(7,8 \%)$ as not being able to use the right to have a break due to the intensity of the work.

\section{Table 2. Frequency and Percentage Distributions of the Participants' Views on the Good Aspects of Working in the Tourism Sector}

$\begin{array}{lcc}\text { The Best Side of Working in Tourism Sector } & \mathbf{n} & \mathbf{\%} \\ \text { Doing the job I like } & 41 & 16.8 \\ \text { Satisfactory wage } & 25 & 10.2 \\ \text { Receiving double wages on special days } & 24 & 9.8 \\ \text { Having a job that requires labor and care } & 23 & 9.4 \\ \text { Appreciated product/Occupational satisfaction } & 20 \\ \text { Having knowledge about world cuisines } & 18 \\ \text { Not being a constant job/Being on the move all the time } & 17 \\ \text { Being able to take part in events such as competition and festival } & 7.4 \\ \text { Having the opportunity to find a job anywhere in the world } & 16 \\ \text { Teaching beginners the occupation } & 16 \\ \text { Pleasing people } & 16 \\ \text { Ensuring the coordination } & 10.6 \\ \text { Being in touch with people } & 6.6 \\ \text { Total } & 6.6 \\ \end{array}$

Source: own processing

Table 3. Frequency and Percentage Distributions of the Participants' Views on the Difficult Aspects of Working in the Tourism Sector

\begin{tabular}{|c|c|c|}
\hline The Hardest Aspect of Working in Tourism Sector & n & $\%$ \\
\hline Lack of social life & 21 & 8.6 \\
\hline Change in working hours and leave days too often & 21 & 8.6 \\
\hline Not being able to spend time with the family & 20 & 8.2 \\
\hline Working on public holidays and holiday celebrations & 19 & 7.8 \\
\hline Not being able to use the right to break due to the intensity of the work & 19 & 7.8 \\
\hline Working in night shift & 18 & 7.4 \\
\hline Fewer annual leave days & 16 & 6.6 \\
\hline Overtime due to mandatory reasons & 15 & 6.1 \\
\hline Working with many people in a restricted space & 15 & 6.1 \\
\hline Long working hours & 14 & 5.7 \\
\hline Trying to keep cost control to a minimum & 12 & 4.9 \\
\hline High risk of work accident and injury & 11 & 4.5 \\
\hline Dealing with impatient customers & 9 & 3.7 \\
\hline Unstable customers who don't know what they want & 7 & 2.9 \\
\hline Approaching female employees with the idea that "they cannot do anything" & 6 & 2.5 \\
\hline Problems with other units & 5 & 2.0 \\
\hline Requiring knowledge of more than one foreign language & 5 & 2.0 \\
\hline Total & 244 & 100 \\
\hline
\end{tabular}

\subsection{Participants' Views on Reasons for Leaving Previous Enterprises}

Table 4 shows the responses and frequency distributions of hotel employees to the question of reasons for leaving their previous workplaces. For this question, 28 participants $(11.5 \%)$ have responded 


\section{JOURNAL OF TOURISM AND SERVICES}

Issue 20, volume 11, ISSN 1804-5650(Online)

www.jots.cz

as the wage not being satisfactory, 27 participants (11.1\%) as doing the job continuously, 25 participants $(10.2 \%)$ as not contributing to professional development, 22 participants $(9.0 \%)$ as the job not coming around as expected and 21 participants $(8.6 \%)$ as work conditions being heavy.

Table 4. Frequency and Percentage Distribution of Participants' Opinions on Reasons for Leaving Previous Enterprises

\begin{tabular}{|c|c|c|}
\hline Reason(s) of Leaving the Previous Workplace & $\mathbf{n}$ & $\%$ \\
\hline Wage not being satisfactory & 28 & 11.5 \\
\hline Doing the same job constantly & 27 & 11.1 \\
\hline Not contributing to professional development & 25 & 10.2 \\
\hline The job not coming out as expected & 22 & 9.0 \\
\hline Heavy working conditions & 21 & 8.6 \\
\hline Not being a corporate enterprise & 20 & 8.2 \\
\hline Grouping among employees & 20 & 8.2 \\
\hline Not getting promoted & 19 & 7.8 \\
\hline Excessive workload by position & 17 & 7.0 \\
\hline Job offer with positions & 16 & 6.6 \\
\hline Problems with superiors & 12 & 4.9 \\
\hline Psychological pressure/Mobbing & 8 & 3.3 \\
\hline I didn't quit my job & 9 & 3.7 \\
\hline Total & 244 & 100 \\
\hline
\end{tabular}

\subsection{Participants' Opinions on Reasons for Ceasing of Employment by Risking Unemployment for a While}

The responses and frequency distributions of the participants to the question "In which situations would you leave without thinking about being unemployed for a while?" are given in Table 5. For this question, 29 participants $(11.9 \%)$ have responded as low wages, 25 participants $(10.2 \%)$ as not getting respect for myself and my job, 25 participants $(10.2 \%)$ as being discriminated, 24 participants $(9.8 \%$, ) as injustice and 23 respondents $(9.4 \%)$ as involuntary overtime work.

Table 5. Frequency and Percentage Distributions of the Participants' Views About on Which Occasions They May Leave Their Jobs by Risking Unemployment for a While

\begin{tabular}{|c|c|c|}
\hline $\begin{array}{l}\text { In what circumstances would you leave without a second thought, by risking unemployment } \\
\text { for a while? }\end{array}$ & $\mathbf{n}$ & $\%$ \\
\hline In cases where the wage earned is low according to the work done & 29 & 11.9 \\
\hline No respect for me and my work & 25 & 10.2 \\
\hline Discrimination & 25 & 10.2 \\
\hline Injustice & 24 & 9.8 \\
\hline Continuous involuntary overtime & 23 & 9.4 \\
\hline Experiencing problems with my colleagues that are difficult to solve & 20 & 8.2 \\
\hline No sense of belonging & 17 & 7.0 \\
\hline Insulting words or behaviors & 15 & 6.1 \\
\hline Problems with superiors & 15 & 6.1 \\
\hline The wage continuously not being paid on payday & 13 & 5.3 \\
\hline Verbal or physical violence & 13 & 5.3 \\
\hline Serious health problems & 11 & 4.5 \\
\hline Abuse & 11 & 4.5 \\
\hline
\end{tabular}


JOURNAL OF TOURISM AND SERVICES

Issue 20, volume 11, ISSN 1804-5650(Online)

www.jots.cz

\subsection{Factors Analysis for Reasons for Ceasing of Employment Scale}

Table 6 exhibits the results of the factor analysis of the participants' "Reasons for Ceasing of Employment" scale.

Table 6. Factor Analysis Results for Participants' Reasons for Ceasing of Employment

\begin{tabular}{|c|c|c|c|c|c|c|}
\hline $\begin{array}{l}\text { Reasons for Hotel } \\
\text { Employees' Ceasing of } \\
\text { Employment }\end{array}$ & 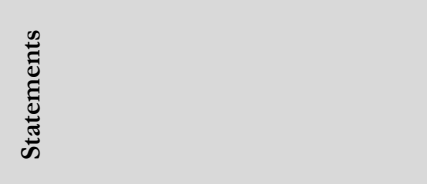 & & 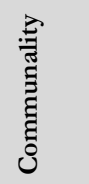 & 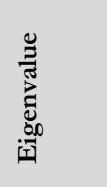 & 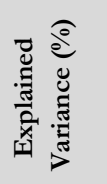 & $\frac{\frac{\pi}{2}}{\frac{2}{4}}$ \\
\hline \multirow{12}{*}{ WORKING CONDITIONS } & Enterprise location & .921 & .929 & \multirow{12}{*}{19.702} & \multirow{12}{*}{82.092} & \multirow{24}{*}{.991} \\
\hline & $\begin{array}{l}\text { Management understanding of } \\
\text { enterprise }\end{array}$ & .898 & .965 & & & \\
\hline & $\begin{array}{l}\text { Employees not being given the } \\
\text { opportunity to demonstrate their } \\
\text { creativity }\end{array}$ & .888 & .943 & & & \\
\hline & $\begin{array}{l}\text { Continuous employee turnover in the } \\
\text { enterprise }\end{array}$ & .887 & .963 & & & \\
\hline & $\begin{array}{l}\text { Employees in the management } \\
\text { position ceasing of employment }\end{array}$ & .873 & .952 & & & \\
\hline & The work not being appreciated & .871 & .930 & & & \\
\hline & Not enough satisfaction with the job & .864 & .948 & & & \\
\hline & $\begin{array}{l}\text { Gender discrimination in the } \\
\text { workplace }\end{array}$ & .851 & .934 & & & \\
\hline & $\begin{array}{l}\text { Ambiguous authorities and } \\
\text { responsibilities }\end{array}$ & .783 & .922 & & & \\
\hline & Difficult physical working conditions & .731 & .870 & & & \\
\hline & Stressful work environment & .727 & .874 & & & \\
\hline & Unethical behaviors in the enterprise & .709 & .921 & & & \\
\hline \multirow{12}{*}{$\begin{array}{c}\text { SOCIAL/ } \\
\text { ECONOMIC CONDITIONS }\end{array}$} & $\begin{array}{l}\text { Lack of business guarantee in the } \\
\text { enterprise }\end{array}$ & .907 & .918 & \multirow{12}{*}{1.816} & \multirow{12}{*}{7.566} & \\
\hline & $\begin{array}{l}\text { Harassment incidents in the } \\
\text { workplace }\end{array}$ & .882 & .924 & & & \\
\hline & Long working hours & .875 & .888 & & & \\
\hline & $\begin{array}{l}\text { Discrimination between employees } \\
\text { (favoritism) }\end{array}$ & .872 & .939 & & & \\
\hline & Low wage level & .827 & .765 & & & \\
\hline & $\begin{array}{l}\text { Unhealthy communication between } \\
\text { employees }\end{array}$ & .813 & .913 & & & \\
\hline & $\begin{array}{l}\text { Inadequate occupational safety } \\
\text { measures }\end{array}$ & .797 & .909 & & & \\
\hline & Conflict between employees & .742 & .767 & & & \\
\hline & Lack of promotion opportunities & .729 & .898 & & & \\
\hline & Lack of incentive and reward system & .722 & .886 & & & \\
\hline & $\begin{array}{l}\text { The negative image of the enterprise } \\
\text { in the public eye }\end{array}$ & .712 & .807 & & & \\
\hline & $\begin{array}{l}\text { Emergence of different job } \\
\text { opportunities }\end{array}$ & .679 & .754 & & & \\
\hline
\end{tabular}




\section{JOURNAL OF TOURISM AND SERVICES}

Issue 20, volume 11, ISSN 1804-5650(Online)

www.jots.cz

KMO Sample Adequacy: .953 - Bartlett Sphericity Test: X²: 13924.567 s.d.: 276 p<0.001

Alpha for the full scale: .989

Response categories: (1) Strongly Disagree (2) Disagree (3) Neither Agree nor Disagree

(4) Agree (5) Strongly Agree

Source: own processing

As a result of the factor analysis to determine the reasons for hotel employees' ceasing of employment, Kaiser-Meyer-Olkin Sample Adequacy for 2 factors (working conditions/social economic conditions) of 24 statements have been calculated as 0.953. For Barttlet's Sphericity Test, chi square $(13924,567$, degree of freedom $(\mathrm{sd})=276, \mathrm{p}<0.001)$ is also significant. Both results indicate the suitability of the data set for factor analysis (Kalayc1, 2010: 321). The reliability of each factor has been tested using Cronbach's alpha coefficients. Reliability levels of the factors are satisfactory and ranged from 0.921 to 0.679. The first factor obtained consisted of 12 statements and explained 82,092\% of the total variance. This factor is called "Working Conditions". The second factor obtained consists of 12 statements and explains $7.566 \%$ of the variance explained. Taking into account the statements in this dimension, the second factor is called "Social and Economic Conditions".

\subsection{Factor Analysis of Occupational Satisfaction Scale}

Table 7 exhibits the results of the factor analysis of the "occupational satisfaction" scale of the participants.

Table 7. Results of Factor Analysis Regarding Participants' Occupational Satisfaction Levels

\begin{tabular}{|c|c|c|c|c|c|c|}
\hline $\begin{array}{l}\text { Occupational Satisfaction } \\
\text { of Hotel Staff }\end{array}$ & 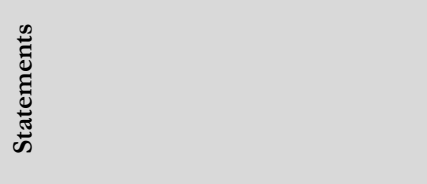 & 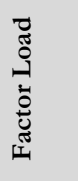 & 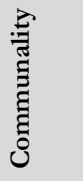 & 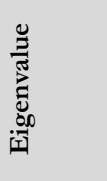 & 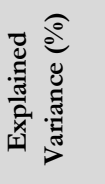 & $\frac{\pi}{\frac{\pi}{2}}$ \\
\hline \multirow{12}{*}{$\begin{array}{l}\text { DESIRE FOR } \\
\text { IMPROVEMENT }\end{array}$} & $\begin{array}{l}\text { I participate in workshops, trainings, } \\
\text { seminars and congresses to increase } \\
\text { my professional knowledge. }\end{array}$ & .874 & .851 & \multirow{12}{*}{14.096} & \multirow{12}{*}{70.479} & \multirow{12}{*}{.967} \\
\hline & $\begin{array}{l}\text { I watch publications about my } \\
\text { profession. (TV, Books, Magazines, } \\
\text { Education, etc.) }\end{array}$ & .870 & .837 & & & \\
\hline & $\begin{array}{l}\text { I take initiatives to increase my } \\
\text { professional knowledge. }\end{array}$ & .803 & .805 & & & \\
\hline & $\begin{array}{l}\text { I try to learn new things about my } \\
\text { work. }\end{array}$ & .729 & .824 & & & \\
\hline & I think my job suits my interests. & .728 & .876 & & & \\
\hline & $\begin{array}{l}\text { I recommend my profession to } \\
\text { others. }\end{array}$ & .694 & .816 & & & \\
\hline & $\begin{array}{l}\text { I find my work important and } \\
\text { meaningful. }\end{array}$ & .685 & .824 & & & \\
\hline & I think my job suits my abilities. & .679 & .722 & & & \\
\hline & $\begin{array}{l}\text { When I meet my colleagues, I ask } \\
\text { them how they do their jobs. }\end{array}$ & .673 & .582 & & & \\
\hline & $\begin{array}{l}\text { If I was born again, I would like to do } \\
\text { the same job. }\end{array}$ & .665 & .845 & & & \\
\hline & I'm doing a job that suits my training. & .661 & .508 & & & \\
\hline & $\begin{array}{l}\text { I struggle with the obstacles I face } \\
\text { while carrying out my profession }\end{array}$ & .599 & .588 & & & \\
\hline
\end{tabular}




\section{JOURNAL OF TOURISM AND SERVICES}

Issue 20, volume 11, ISSN 1804-5650(Online)

www.jots.cz

Table 8. Findings for Correlation between the Reasons for Ceasing of Employment and Its SubDimensions and Occupational Satisfaction Level and Its Sub-Dimensions

\begin{tabular}{|c|c|c|c|c|}
\hline & & $\begin{array}{l}\text { Occupational } \\
\text { Satisfaction }\end{array}$ & $\begin{array}{l}\text { Occupational } \\
\text { Satisfaction / } \\
\text { Desire for } \\
\text { Improvement }\end{array}$ & $\begin{array}{c}\text { Occupational } \\
\text { Satisfaction / } \\
\text { Compliance } \\
\text { with } \\
\text { Qualifications }\end{array}$ \\
\hline \multirow[t]{3}{*}{$\begin{array}{l}\text { Reasons for } \\
\text { Ceasing of } \\
\text { Employment }\end{array}$} & \multirow{3}{*}{$\begin{array}{l}\text { Pearson } \\
\text { Correlation } \\
\text { Sig. (2- } \\
\text { tailed) } \\
\text { N }\end{array}$} & .062 & .065 & .053 \\
\hline & & .336 & .311 & .408 \\
\hline & & 244 & 244 & 244 \\
\hline \multirow[t]{3}{*}{$\begin{array}{l}\text { Operating } \\
\text { Conditions }\end{array}$} & \multirow{3}{*}{$\begin{array}{l}\text { Pearson } \\
\text { Correlation } \\
\text { Sig. (2- } \\
\text { tailed) } \\
\text { N }\end{array}$} & .079 & & \\
\hline & & .221 & & \\
\hline & & 244 & & \\
\hline \multirow[t]{3}{*}{$\begin{array}{l}\text { Social/Economic } \\
\text { Conditions }\end{array}$} & \multirow{2}{*}{$\begin{array}{l}\text { Pearson } \\
\text { Correlation } \\
\text { Sig. (2- } \\
\text { tailed) }\end{array}$} & .033 & & \\
\hline & & .603 & & \\
\hline & $\mathbf{N}$ & 244 & & \\
\hline
\end{tabular}

\subsection{Regression Analysis}

\subsubsection{Findings on the Regression Relationship Between Reasons for Ceasing of Employment and Occupational Satisfaction Level}

Regression analysis has been carried out in order to determine the effect of the reasons for ceasing of employment job dimensions on occupational satisfaction levels and the results are presented in Table 9 .

When the results of the simple linear regression analysis are examined, it is observed that the managers' reasons to cease the employment do not have a statistically significant effect on the occupational satisfaction levels ( $\mathrm{p}>0.05)$. 


\section{JOURNAL OF TOURISM AND SERVICES}

Issue 20, volume 11, ISSN 1804-5650(Online)

www.jots.cz

Table 9. The Effects of Reasons for Ceasing of Employment on Occupational Satisfaction Level

\begin{tabular}{|c|c|c|c|c|c|c|c|}
\hline \multirow[b]{2}{*}{ Model } & \multicolumn{2}{|c|}{$\begin{array}{l}\text { Non-standardized } \\
\text { Coefficients }\end{array}$} & \multirow{2}{*}{$\begin{array}{c}\begin{array}{c}\text { Standardized } \\
\text { Coefficients }\end{array} \\
\text { Beta }\end{array}$} & \multirow{2}{*}{$\mathbf{T}$} & \multirow{2}{*}{$\begin{array}{l}\text { Significance } \\
\text { Level }\end{array}$} & \multirow{2}{*}{ Tolerance } & \multirow{2}{*}{ V.I.F. } \\
\hline & B & $\begin{array}{l}\text { Std. } \\
\text { Error }\end{array}$ & & & & & \\
\hline (Stable) & 3.744 & .196 & & 19.144 & .000 & & \\
\hline $\begin{array}{l}\text { Reasons for Ceasing of } \\
\text { Employment }\end{array}$ & .056 & .058 & .062 & .964 & .336 & 1.000 & 1.000 \\
\hline
\end{tabular}

Source: own processing

4.7.2. Findings on the Regression Relationship Between Job Reasons and Sub-dimensions of Job Satisfaction

Regression analysis of the sub-dimensions of the variable has been performed to determine the effect of dimensions of the reasons for ceasing of employment on the level of occupational satisfaction, and the results have been presented in Table 10.

Table 10. The Effects of Sub-Dimensions of the Reasons for Ceasing of Employment on Occupational Satisfaction Level

\begin{tabular}{|c|c|c|c|c|c|c|c|}
\hline \multirow[b]{2}{*}{ Model } & \multicolumn{2}{|c|}{$\begin{array}{l}\text { Non-standardized } \\
\text { Coefficients }\end{array}$} & \multirow{2}{*}{$\begin{array}{c}\text { Standardized } \\
\text { Coefficients }\end{array}$} & \multirow[t]{2}{*}{$\mathbf{t}$} & \multirow{2}{*}{$\begin{array}{c}\text { Significance } \\
\text { Level }\end{array}$} & \multirow[t]{2}{*}{ Tolerance } & \multirow[t]{2}{*}{ V.I.F. } \\
\hline & B & Std. Error & & & & & \\
\hline (Stable) & 4.145 & .374 & & 11.093 & .000 & & \\
\hline $\begin{array}{l}\text { Reasons for Ceasing of } \\
\text { Employment/Working } \\
\text { Conditions }\end{array}$ & .138 & .092 & .184 & 1.497 & .136 & .272 & 3.677 \\
\hline $\begin{array}{l}\text { Reasons for Ceasing of } \\
\text { Employment/Social } \\
\text { Economic Conditions }\end{array}$ & -.128 & .127 & -.123 & -1.005 & .316 & .272 & 3.677 \\
\hline \multicolumn{8}{|c|}{ Dependent Variable: Occupational Satisfaction } \\
\hline R: 0 . & .010 & $\mathrm{R}^{2:} 0$. & r model: 1 . & $=0$ & sd: 2; DV & 959 & \\
\hline
\end{tabular}

Source: own processing

When the results of multiple linear regression analysis are examined, it is observed that the model is meaningless $(\mathrm{p}>0.05)$. The t statistics, which indicate the significance of regression coefficients, are not significant for reasons for ceasing of employment/working conditions $(t=1.497, p>0.05)$ and reasons for ceasing of employment/social/economic conditions $(t=-1.005, p>0.05)$. According to this result " $\mathrm{H}_{2}$ Reasons for hotel employees' ceasing of employment affect their occupational satisfaction" is rejected. 


\section{JOURNAL OF TOURISM AND SERVICES}

Issue 20, volume 11, ISSN 1804-5650(Online)

www.jots.cz

\section{Conclusion, Discussion and Suggestions}

This study aims to determine the relationship between reasons for ceasing of employment and job satisfaction of the employees of the food, beverage and kitchen department working in three, four and five star hotels operating in Eskişehir. When the opinions of the food and beverage and culinary department employees about the good parts of the working in the tourism are examined, it is observed that the majority of them have stated that they do their favorite work. They have also stated that their salaries are satisfactory, that they received double wages on special days, that their jobs require care, that they have occupational satisfaction as a result of the appreciation of the product and that their positions create the opportunity to find jobs in many parts of the world. In support of this finding, Ghiselli et al. (2001) have found that food and beverage department managers are satisfied with their jobs and provide continuity to their jobs if they are satisfied with their salaries. Kim et al. (2005) have stated that opportunities for promotion, pleasure from the work done, creative works increase the satisfaction levels of hotel staff and create a sense of belonging. In their study to determine the effects that affect the professional satisfaction level of employees and cause them to cease the employment; Khan \& Aleem (2014) have concluded that wages and bonuses increase employee loyalty, promotion, working conditions and the quality of work done are an important factor in job satisfaction and affect ceasing of employment. Supporting this result, Mulyani, Sari \& Sari (2019) have stated that compensation has an important contribution to the performance of employees. They have also emphasized that wages increase employee motivation and employee performance, and job satisfaction has a dominant effect on employee performance.

Participants have stated that, as a difficult part of working in the tourism sector, they can spend less time for their social lives and families, working hours and leave days change frequently, they have to work on public holidays and holiday celebration and work overtime against their will due to mandatory reasons and their working hours are long. The conclusion obtained in the research is also consistent with the researches of Fiksenbaum et al. (2010). It has been concluded that excessive work intensity, long working hours and overtime in hotel managers affect burnout and job-family conflict and lead to resignation. At the same time, Tuncer \& Yeşiltaş (2013) concluded that improvements in work life can be increased and the level of employment of hotel employees can be reduced.

When the findings of the food and beverage and kitchen department employees' reasons for leaving their previous jobs are evaluated, it is observed that they complain about the fact that the wages are not at the most satisfactory level, that they do the same job continuously, do not contribute to their professional development, that the job is not as expected, that the working conditions are not institutional, as well as about factors such as difficulties in getting promotions or receiving job offers, grouping among employees or having problems with superiors and being exposed to psychological pressure. Consistent with this finding in the literature, Üngüren, Cengiz \& Algür (2009) have stated that factors such as wages, awards and promotion opportunities, job security, working conditions, management style, quality of work, social opportunities and inter-employee communication affect occupational satisfaction, and these factors should be improved and that they would increase ceasing of employment if not provided. This is similar to the study of Çivilidağ (2014). It has been found that excessive workload, long working hours, shift work obligation, low wages, unauthorized working days, unfair rewarding and promotion system, lack of support among the employees and inadequate physical conditions in the working environment affect the hotel employees and create mobbing, burnout and job dissatisfaction on the employees. Supporting this result, Djoemadi, Setiawan, Noermijati and Irawanto (2019) have stated that working conditions are important in employee loyalty, followed by working relationships and promotion. They have stated that working conditions include occupational safety, job comfort, stress levels, working hours and management policies, and that employees' continuing to work can be achieved by improving these factors. 


\section{JOURNAL OF TOURISM AND SERVICES}

Issue 20, volume 11, ISSN 1804-5650(Online)

www.jots.cz

The participants have stated that the reasons for leaving the job by considering being unemployed for a while are that the wages earned according to the nature of the job and their responsibilities are low, that their salaries are not paid on the day, and that they have to work overtime continuously. At the same time, they state that they will risk leaving their jobs in the event that they are not respected for themselves and their work, the presence of degrading words and behaviors, verbal or physical violence, being faced with discrimination and injustice in the workplace, experiencing difficulty to solve the feelings of belonging as a result of the lack of belonging and serious health problems if they live, they will risk leaving the job. In line with this result, in their study aimed to determine the effect of employee loyalty and job stress on organizational performance; Hidayati, Lestari, Maria and Zainurossalamia (2019) have concluded that employee loyalty increases organizational performance and stressful events in the workplace reduce employee loyalty. Female employees intend to quit because of pregnancy or harassment at work. Liu \& Yang (2009) state that remuneration, organizational structure, hotel management and employee relations have a significant effect on job satisfaction of hotel employees. Knox (2008), on the other hand, concluded that gender-based occupational discrimination in hotels is experienced especially in kitchen departments.

As a result of the correlation analysis conducted in order to determine whether there is a significant relationship between the reasons for layoffs and occupational satisfaction levels, the hypothesis "There is a significant relationship between reasons for hotel employees' ceasing of employment and occupational satisfaction levels" has been rejected. Contrary to this result, Fulford (2005) concluded that occupational satisfaction had an indirect effect on organizational commitment and reasons for ceasing of employment. In support of this result, Kuruüzüm et al. (2009) have conducted a study in five-star hotels in the Antalya region in order to determine the structural relationships between the dimensions of participation, job satisfaction and organizational commitment in the accommodation sector, and emphasized that the participation in the work increases the job satisfaction and enhances the organizational commitment of the employees. emphasized that the emotional factors of the employees affect the continuity and organizational commitment and are related to professional satisfaction. Aydoğdu \& Aş1kgil (2011) concluded that the decrease in the level of occupational satisfaction would lead to an increase in the number of employees. Similarly, Chiang et al. (2005) have concluded that job satisfaction positively influenced the continuation of work in the studies conducted to determine the factors that increase the training, job satisfaction and continuity of the employees in the hotel industry. In their study, Lu et al. (2016) concluded that job satisfaction affects employees' decision to quit and that participation increases job satisfaction.

According to the results of the regression analysis, it is concluded that the employees' reasons to cease the employment does not have a significant effect on their occupational satisfaction levels. According to this result, the hypothesis "Reasons for hotel employees' ceasing of employment affect their occupational satisfaction" is rejected. However, contrary to this conclusion in the literature, Sangaran \& Teetesh (2015) have concluded in their research made to determine the job satisfaction factors and ceasing of employment factors in the hotels that job satisfaction is closely related to the wage, promotion, security, social services, moral values, authority, status of the employees in the food and beverage and that it is related to ceasing of employment. Similarly, Jung \& Yoon (2016) examined the effects of job satisfaction on ceasing of employment in the food and beverage department of a hotel business and emphasized that the satisfaction of the employee affects their ceasing of employment and the employees who provide satisfaction from their work do not think of ceasing of employment. Uludag et al. (2011) similarly concluded that factors such as excessive workload, burnout and job family conflict are effective on the decision to quit and job satisfaction.

Generally speaking, low wage level is important for hotel employees' decision for ceasing of employment. Considering the quality of their work and the time they spend in business life, it is inevitable for the employees to increase their skills, to improve their jobs, and to want to be promoted when they consider their long-term work in the company. Failure of the expected promotion may create negative 


\section{JOURNAL OF TOURISM AND SERVICES}

Issue 20, volume 11, ISSN 1804-5650(Online)

www.jots.cz

thoughts in the employee. Physical working conditions are important for the employees to do their jobs in accordance with their qualifications, to enjoy the working environment and to work healthy. At the same time, the uncomfortable physical work environment can lead to undesirable situations such as employee accidents. Depressing and demotivating factors such as long working hours in the workplace, stressful working environment, presence of discrimination among employees, unethical behaviors in the enterprise, management style, harassment, insufficient occupational safety measures cause the employees to lose their commitment to their jobs. The existence of incentive practices such as appreciation of the work done for the employees to provide satisfaction from their work, the opportunity to show their creativity, and bonuses and premiums reinforce the employee's commitment to the business and the enterprise. Employees are important in terms of conducting business activities without disruption. The loss of employees who fulfill their job responsibilities and are aware of the objectives of the enterprise may cause serious losses for the enterprises. If the employee ceases the employment, the training of the replacement personnel, the time required to adapt to the enterprise and the organization, and the financial loss caused by the personnel employment and dismissal may cause problems in the enterprises. Therefore, enterprises should take into consideration the occupational satisfaction of the employees and should strive to create satisfied personnel who are satisfied with their jobs. This study is considered to be important for hotel businesses, managers and hotel staff. In particular, some suggestions can be made to avoid ceasing of employment and to increase the level of occupational satisfaction:

- Management should pay attention to improving the competencies and skills of employees.

- Employees should be rewarded for increasing their satisfaction and encouraging their success.

- The professional level of the employees should be increased, their self-confidence should be revealed and their organizational commitment should be strengthened.

- Fair promotion opportunities should be provided to employees and career strengthening opportunities should be created.

- In the enterprise, a management understanding that trusts, respects and encourages highly motivated employees striving for professional development should be established.

- Managers should regularly monitor job satisfaction and satisfaction of employees and evaluate their progress and reward employees to increase their productivity.

- It should be taken into consideration that thanks to the organizational support to be provided to the employees, the adoption of common goals in the enterprise and the level of occupational satisfaction will increase.

- It should be taken into consideration that employees will be exposed to harassment, insults, stress and pressure as a result of their employment.

- If managers are focused on maximizing the job satisfaction of employees, inability to resolve management conflicts of employees, low motivation, increasing role conflicts, intergroup tensions, communication disruptions, low performance problems can be minimized.

- Managers should increase employee satisfaction by providing good job opportunities and improving their working environment. This will prevent employees from leaving the business.

There are various limitations in the research conducted. The first limitation of the study was assumed to be limited to the items in the scale and the responses to the items, to determine the relationship between the reasons for ceasing of employment and the professional satisfaction of the employees working in the food and beverage and kitchen departments in the hotel enterprises. The second limitation is that, due to the voluntary participation in the research, the workload of the employees, their leave or report, no questionnaire has applied to all of the personnel working in the hotels. Therefore, generalization cannot be made within the scope of the research. Repeating and implementing a similar study for all hotel business employees by covering the entire sector will make the study generalizable. Another limitation is that there are few studies in the literature on the employees' reasons to cease the employment and their level of professional satisfaction working in the food and 


\section{JOURNAL OF TOURISM AND SERVICES}

Issue 20, volume 11, ISSN 1804-5650(Online)

www.jots.cz

beverage and kitchen departments of the hotel businesses. It is thought that the study will fill the gap in the literature and may be a source for future studies.

\section{References}

1. Aguinis, H., Boik, R. J. \& Pierce, C., A. (2001). A Generalized Solution for Approximating the Power to Detect Effects of Categorical Moderator Variables Using Multiple Regression. Organizational Research Methods, 4(4), 291-323. doi:10.1177/109442810144001

2. Akinc1, Z. (2002). Factors which Affect Job Satisfaction in the Tourism Sector: A Survey in Five Star Hospitality Organizations. Akdeniz University Journal of Economics and Administrative Sciences, (4), 1-25.

3. Aktaş, H. \& Kilınç, T. (2007). The Relationships Between Conflict Management Approaches of the Managers of Five Star Hotels Members of TUROB and Their Interpersonal Conflict Management Styles. İstanbul Üniversitesi İsletme İktisadı Enstitüsü Dergisi, 18(18), 76-87.

4. Androniceanu, A. (2019). Social responsibility, an essential strategic option for a sustainable development in the field of bio-economy, Amfiteatru Economic, 21(52), 347-364

5. Aşık, N. A. (2010). A Conceptual Evaluation of Individual and Organizational Factors Affecting Employees' and Results of Job Satisfaction. Türk İdare Dergisi, 467(6), 31-51.

6. Aydın, İ. (2002). Iss Yaşamında Stres. Ankara: Pegem Akademi Publishing.

7. Aydın, Ş. (2004). Otel İşletmelerinde Örgütsel Stres Faktörleri: 4-5 Yıldızlı Otel İşletmeleri Uygulamasi. Dokuz Eylul University The Journal of Graduate School of Social Sciences, 6(4), 1-21.

8. Aydoğdu, S. \& Aşıkgil, B. (2011). An Empirical Study of the Relationship Among Job Satisfaction, Organizational Commitment and Turnover Intention. International Review of Management and Marketing, 1(3), 43-53.

9. Aziri, B. (2011). Job Satisfaction: A Literature Review. Management Research \& Practice, 3(4), 77-86.

10. Bacik, R., Kmeco, L., Richard, F., Olearova, M., \& Rigelsky, M. (2019). Marketing Instrument of Improving Hotel Management Service: Evidence of Visegrad Group Countries. Marketing and Management of Innovations, 208-220. doi:10.21272/mmi.2019.1-17

11. Bakan, İ. \& Büyükbeşe, A. G. T. (2004). Çalışanların İş Güvencesi ve Genel İş Davranışları İlişkisi: Bir Alan Çalışması. Erciyes University Journal of Faculty of Economics and Administrative Sciences, (23), 35-59.

12. Barling, J., Kelloway, E. K. \& Iverson, R., D. (2003). High-Guality Work, Job Satisfaction, and Occupational Injuries. Journal of Applied Psychology, 88(2), 276-283doi:10.1037/0021-9010.88.2.276

13. Barutçugil, İ. (2004). Stratejik Insan Kaynakelar Yönetimi. Kariyer Publishing.

14. Başaran, İ. E. (2000). Örgütse IDavranış. Ankara: Feryal Publishing.

15. Baybora, D. (2010). Çalışma Yaşamında Yaş Ayrımcılı̆̆1 ve Amerika Birleşik Devletleri'nde Yaş Ayrımcilığ1 Düzenlemesi Üzerine. Calısma ve Toplum Dergisi, 24, 33-58.

16. Belas, J., Cipovova, E., \& Demjan, V. (2014). Current trends in area of satisfaction of bank clients in the Czech republic and Slovakia. Tranformations in Business and Economics, 13(3): 219-234.

17. Berg, P. \& Frost, A. (2005). Dignity at Work for Low Wage, Low Skill Service Workers. Relations Industrielles/Industrial Relations, 60(4), 657-682.Doi:10.7202/012339ar

18. Biggs, J., Kember, D. \& Leung, D., Y. (2001). The Revised Two Factor Study Process Questionnaire: R-SPQ-2F. British Journal of Educational Psychology, 71(1), 133-149. doi:10.1348/000709901158433

19. Bingöl, D. (2003). Insan Kaynaklar Yönetimi. İstanbul: Beta Publishing. 


\section{JOURNAL OF TOURISM AND SERVICES}

Issue 20, volume 11, ISSN 1804-5650(Online)

www.jots.cz

20. Birdir, K. \& Tepeci, M. (2003). Otel Genel Müdürlerinde Tükenmişlik Sendromu ve Tükenmişliğin Genel Müdürlerin İşlerini Değisstirme Eğilimlerine Etkisi. Anatolia: A journal of Tourism Research, 14(2), 93-106.

21. Bohle, P., Quinlan, M., Kennedy, D. \& Williamson, A. (2004). Working Hours, Work-Life Conflict and Health in Precarious and "Permanent" Employment. Revista de Saúde Pública, 38, 1925.

22. Bonn, M., A. \& Forbringer, L. R. (1992). Reducing Turnover in the Hospitality Industry: An Overview of Recruitment, Selection and Retention. International Journal of Hospitality Management, 11(1), 47-63.

23. Brown, E., A., Thomas, N., J. \& Bosselman, R., H. (2015). Are they Leaving or Staying: A Qualitative Analysis of Turnover Issues for Generation Y Hospitality Employees with a Hospitality Education. International Journal of Hospitality Management, 46, 130-137. doi:10.1016/j.ijhm.2015.01.011

24. Bulut, E. ve Çavuş G. (2015). Liderlik, Motivasyon ve Ödüllendirme İlişkilerinin İncelenmesinde Kısmi En Küçük Kareler Yol Analizinin Kullanılması. Çankır Karatekin Üniversitesi İ̈BF Dergisi, 5(2), 591-614. doi:10.18074/cnuiibf.238

25. Chiang, C. F., Back, K. J. ve Canter, D. D. (2005). The Impact of Employee Training on Job Satisfaction and Intention to Stay in the Hotel Industry. Journal of Human Resources in Hospitality \& Tourism, 4(2), 99-118. doi:10.1300/J171v04n02_06

26. Choi, K. (2006). A Structural Relationship Analysis of Hotel Employees' Turnover Intention. Asia Pacific Journal of Tourism Research, 11(4), 321-337. doi:10.1080/10941660600931150

27. Chromjakova, F. (2016). The Key Principles of Process Manager Motivation in Production and Administration Processes in an Industrial Enterprise. Journal of Competitiveness, 8(1), 95-110. doi:10.7441/joc.2016.01.07

28. Ciobanu, A, Androniceanu, A \& Lazaroiu, G. (2019). An integrated psycho-sociological perspective on public employees' motivation and performance. Frontiers in Psychology, 10:36. doi: 10.3389/fpsyg.2019.00036

29. Cleveland, J., N., O'Neill, J., W., Himelright, J., L., Harrison, M., M., Crouter, A., C. \& Drago, R. (2007). Work and Family Issues in the Hospitality Industry: Perspectives of Entrants, Managers, and Spouses. Journal of Hospitality \& Tourism Research,31(3), 275-298. doi:10.1177/1096348007299919

30. Cruz, F., G., S., López-Guzmán, T. \& Cañizares, S., M., S. (2014). Analysis of Job Satisfaction in the Hotel Industry: A Study of Hotels in Spain. Journal of Human Resources in Hospitality \& Tourism, 13(1), 63-80. doi:10.1080/15332845.2013.807394

31. Çakınberk, A., Derin, N. \& Gül, G. (2011). Employee Turnover Rate Analysis in Terms of Human Resources in Tourism Business: The Case of Cappadocia Region. Elektronic Journal of Social Sciences, 10(36), 252-272.

32. Çanakçı, T. (2018). Dört ve Beş Yıldızlı Otel Mutfak Şeflerinin Işten Ayrılma Nedenleri. Mersin University Social Sciences Institute Department of Tourism Management, Mersin.

33. Çivilidağ, A. (2014). Hotel Employees' Mobbing, Burnout, Job Satisfaction and Perceived Organizational Support: A Research on Hospitality in Turkey. European Scientific Journal, 10(35), $1-22$.

34. Demirel, Y. (2011) İş Yerinde Ayrımcıllk: Kavramsal Bir İnceleme. TİSK Akademi, 2, 67-87.

35. Demirel, M. (2014). Burdur City Image: A Case Study on Mehmet Akif Ersoy University Students. Mebmet Akif Ersoy University Journal of Social Sciences Institute, 6(10), 230-241.

36. Dienhart, J. R. \& Gregoire, M. B. (1993). Job Satisfaction, Job Involvement, Job Security, and Customer Focus of Quick-Service Restaurant Employees. Hospitality Research Journal, 16(2), 29-43. doi:10.1177/109634809301600205 


\section{JOURNAL OF TOURISM AND SERVICES}

Issue 20, volume 11, ISSN 1804-5650(Online)

www.jots.cz

37. Djoemadi, F. R., Setiawan, M., Noermijati, N. \& Irawanto, D. W. (2019). The Effect of Work Satisfaction on Employee Engagement. Polish Journal of Management Studies, 19(2), 101-111. doi:10.17512/pjms.2019.19.2.08

38. Erdem, B. (2003). Otel İşletmelerinde İnsan Kaynakları Planlamasının Yeri ve Önemi. ISGUC The Journal of Industrial Relations and Human Resources,5(2), 35-54.

39. Erdoğan, İ. (1994). Issletmelerde Davranıs. İstanbul: Beta Publishing.

40. Eren, E. (2003). Yönetim ve Organizasyon: Căgdas ve Küresel Yaklaşımlar. İstanbul: Beta Publishing.

41. Erlinghagen, M. (2007). Self-Perceived Job Insecurity and Social Context: A Multi-Level Analysis of 17 EuropeanCountries. European Sociological Review, 24(2), 183-197. doi:10.1093/esr/jcm042

42. Eroğlu, F. (2000). Davranıs Bilimleri. İstanbul: Beta Publishing.

43. Eskildsen, J. K., Kristensen, K. \& Westlund, A. H. (2004). Work Motivation and Job Satisfaction in the Nordic Countries. Employee Relations, 26(2), 122-136. doi:10.1108/01425450410511043

44. Fay, C., H. \& Thompson, M., A. (2001). Contextual Determinants of Reward Systems' Success: An Exploratory Study. Human Resource Management: Published in Cooperation with the School of Business Administration, The University of Michigan and in Alliance with the Society of Human Resources Management, 40(3), 213-226. doi:10.1002/hrm.1012

45. Felicita, C. (2016). The Key Principles of Process Manager Motivation in Production and Administration Processes in an Industrial Enterprise. Journal of Competitiveness, 8(1), 95-110. doi:10.7441/joc.2016.01.07

46. Fiksenbaum, L., Jeng, W., Koyuncu, M. \& Burke, R., J. (2010). Work Hours, Work Intensity, Satisfactions and Psychological Well Being Among Hotel Managers in China. Cross Cultural Management: An International Journal. 17(1), 79-93. doi:10.1108/13527601011016925

47. Frye, W., D. \& Mount, D., J. (2007). An Examination of Job Satisfaction of General Managers Based on Hotel Size and Service Type. Journal of Human Resources in Hospitality \& Tourism, 6(2), 109-134.doi:10.1300/J171v06n02_06

48. Fulford, M. D. (2005). That's not Fair! The Test of a Model of Organizational Justice, Job Satisfaction, and Organizational Commitment Among Hotel Employees. Joumal of Human Resources in Hospitality \& Tourism, 4(1), 73-84. doi:10.1300/J171v04n01_06

49. Gaertner, S. (1999). Structural Determinants of Job Satisfaction and Organizational Commitment in Turnover Models. Human Resource Management Review, 9(4), 479-493. doi:10.1016/S10534822(99)00030-3

50. Gavcar, E. \& Topaloğlu, C. (2008). Kamuya Ait Konaklama İşletmelerinin Yöneticilerinde İş Doyumu (Öğretmenevi Müdürleri Örneği). Yönetim Bilimleri Dergisi, 6(2), 59-74.

51. Genç, S., G. ve Genç, V. \& Gümüş, M. (2016). The Effect of Emotional Intelligence on Job Stress and Work Life Balance in Hotel Businesses. Batman University Journal of Life Sciences, 6(2/1), 97-112.

52. George, D. \& Mallery, P. (2003). SPSS for Windows Step By Step: A Simple Guide and Reference 11.0 Update. Boston: Allyn \& Bacon.

53. Ghiselli, R. F., Lopa, J. M. \& Bai, B. (2001). Job Satisfaction, Life Satisfaction, and Turnover Intent: Among Food-Service Managers. Cornell Hotel and Restaurant Administration Quarterly, 42(2), $28-37$.

54. Gilbert, D., Guerrier, Y. \& Guy, J. (1998). Sexual Harassment Issues in the Hospitality Industry. International Journal of Contemporary Hospitality Management, 10(2), 48-53. doi.org/10.1108/09596119810207183

55. Giritlioğlu, İ. \& Özlü, B. (2016). The Perception of Work Satisfaction and Turnover Rate of Food and Beverage Among Food and Beverage Employees in Hotel Enterprises: A Case Study on the City Hotels of Gaziantep. TheJournal of International Social Research, 9(43), 1847-1862. doi:10.17719/jisr.20164317754 


\section{JOURNAL OF TOURISM AND SERVICES}

Issue 20, volume 11, ISSN 1804-5650(Online)

www.jots.cz

56. Groot, W. \& Brink, H. (1999). Job Satisfaction of Older Workers. International Journal of Manpower, 20(6), 343-360. doi:10.1108/01437729910289701

57. Gümüştekin, G., E. \& Öztemiz, A., B. (2005). Örgütlerde Stresin Verimlilik ve Performansla Etkileşimi. Cukurova Üniversitesi Sosyal Bilimler Enstitüsü Dergisi, 14(1), 271-288.

58. Hang-Yue, N., Foley, S. \& Loi, R. (2005). Work Role Stressors and Turnover Intentions: A Study of Professional Clergy in Hong Kong. The International Journal of Human Resource Management, 16(11), 2133-2146. doi:10.1080/09585190500315141

59. Heller, D., Judge, T. A. \& Watson, D. (2002). The Confounding Role of Personality and Trait Affectivity in the Relationship Between Job and Life Satisfaction. Journal of Organizational Behavior: The International Journal of Industrial, Occupational and Organizational Psychology and Behavior, 23(7), 815835. doi:10.1002/job.168

60. Hellgren, J., Sverke, M. \& Isaksson, K. (1999). A Two-Dimensional Approach to Job Insecurity: Consequences for Employee Attitudes and Well-Being. European Journal of Work and Organizational Psychology, 8(2), 179-195. doi:10.1080/135943299398311

61. Hidayati, T., Lestari, D. Maria, S. \& Zainurossalamia, S. (2019). Effect of Employee Loyalty and Commitment on Organizational Performance with Considering Role of Work Stress. Polish Journal of Management Studies, 20(2), 256-266. https://doi.org/10.29036/jots.v9i16.40

62. Horváth, Zs., \& Hollósy, V. G. (2019). The revision of Hungarian public service motivation (PSM) model. Central European Journal of Labour Law and Personnel Management, 2 (1), 17-28. doi: 10.33382/cejllpm.2019.02.02

63. Hu, H. H. \& Cheng, C. W. (2010). Job Stress, Coping Strategies, and Burnout Among Hotel Industry Supervisors in Taiwan. The International Journal of Human Resource Management, 21 (8), 13371350. doi:10.1080/09585192.2010.483867

64. Ibrahim, R. A. T. (2019). Management of organizational cultures and job performance: the case for GCC companies. Marketing and Management of Innovations, 3, 265-271. doi:10.21272/mmi.2019.3-20

65. Ince, C. (2008). Total Quality Management and its Effects on Employee Satisfaction in Hotel Businesses. Anatolia: A Journal of Tourism Research, 19(1), 57-70.

66. İnce, C. (2015). Employee Turnover in Turkısh Food \& Beverage Business in Bishkek, Kyrgyzstan. Kastamonu University Journal of Economics \& Administrative Sciences Faculty, 6(4), 35-51.

67. Judge, T. A., Jackson, C. L., Shaw, J. C., Scott, B. A. \& Rich, B. L. (2007). Self-Efficacy and WorkRelated Performance: The Integral Role of Individual Differences. Journal of Applied Psychology, 92(1), 107. doi:10.1037/0021-9010.92.1.107

68. Jung, H., S. \& Yoon, H., H. (2017). Error Management Culture and Turnover Intent Among Food and Beverage Employees in Deluxe Hotels: The Mediating Effect of Job Satisfaction. Service Business, 11(4), 785-802. doi:10.1007/s11628-016-0330-5

69. Kalayc1, S.. (2010). SPSS Uygulamah Cok Değişkenli İstatistik Teknikleri. Ankara: Asil Publishing.

70. Kaya, H. \& Abdioğlu, H. (2010). An Empirical Study on Employee Turnover Tendency. TODADE's Review of Public Administration, 4(4), 141-183.

71. Kayış, A. (2010). Güvenilirlik Analizi. İçinde: Ş. Kalayc1 (Ed.), SPSS Uygulamalı Çok Değişkenli Istatistik Teknikleri (pp. 403-419). Ankara: Asil Publishing.

72. Khan, A. H., \& Aleem, M. (2014). Impact of Job Satisfaction on Employee Turnover: An Empirical Study of Autonomous Medical Institutions of Pakistan. Journal of International Studies, 7(1), 122-132. doi:10.14254/2071-8330.2014/7-1/11

73. Kim, K. \& Jogaratnam, G. (2010). Effects of Individual and Organizational Factors on Job Satisfaction and Intent to Stay in the Hotel and Restaurant Industry. Journal of Human Resources in Hospitality \& Tourism, 9(3), 318-339. doi:10.1080/15332845.2010.487043 


\section{JOURNAL OF TOURISM AND SERVICES}

Issue 20, volume 11, ISSN 1804-5650(Online)

www.jots.cz

74. Kim, W. G., Leong, J. K. \& Lee, Y. K. (2005). Effect of Service Orientation on Job Satisfaction, Organizational Commitment and Intention of Leaving in a Casual Dining Chain Restaurant. International Journal of Hospitality Management, 24(2), 171-193. doi:10.1016/j.ijhm.2004.05.004

75. Kline, S., \& Hsieh, Y. C. J. (2007). Wage differentials in the lodging industry: A case study. Journal of Human Resources in Hospitality \& Tourism, 6(1), 69-84. doi:10.1300/J171v06n01_04

76. Knouse, S. B. \& Giacalone, R. A. (1992). Ethical Decision-Making in Business: Behavioral Issues and Concerns. Journal of Business Ethics, 11(5-6), 369-377. doi:10.1007/BF00870549

77. Knox, A. (2008). Gender Desegregation and Equal Employment Opportunity in Australian Luxury Hotels: Are we there yet?.Asia Pacific Journal of Human Resources, 46(2), 153-172. doi:10.1177/1038411108091756.

78. Kontoghiorghes, C. (2001). A Holistic Approach Toward Motivation to Learn in the Workplace. Performance Improvement Quarterly, 14(4), 45-59. doi:10.1111/j.19378327.2001.tb00229.x

79. Kot-Radojewska, M., \& Timenko, I. V. (2018). Employee loyalty to the organization in the context of the form of employment. Oeconomia Copernicana, 9(3), 511-527. doi:10.24136/oc.2018.026

80. Koyuncu, M., B. \& Sevin, H., D. (2017). The Effects of Psychologial Violence Perceptions of Hospitality Employees to Job Satisfaction. Journal of Management, Economic and Marketing Research, 1(3), 33-52.

81. Kumari, G. \& Pandey, K. M. (2011). Job Satisfaction in Public Sector and Private Sector: A Comparison. International Journal of Innovation, Management and Technology, 2(3), 221-228. doi:10.7763/IJIMT.2011.V2.135

82. Kuruüzüm, A., Çetin, E., İ. \& Irmak, S. (2009). Path Analysis of Organizational Commitment, Job Involvement and Job Satisfaction in Turkish Hospitality Industry. Tourism Review, 64(1), 4-16. doi:10.1108/16605370910948821

83. Kuzgun, Y., Sevim, S., A. \& Hamamc1, Z. (1999). Developing of Job Satisfaction Scale, Turkish Psychological Counseling and Guidance Journal, 2(11), 14-18.

84. Lam, T., Baum, T. \& Pine, R. (2001). Study of Managerial Job Satisfaction in Hong Kong's Chinese Restaurants. International Journal of Contemporary Hospitality Management, 13(1), 35-42. doi:10.1108/09596110110365634

85. Lawler, E. E. \& Porter, L. W. (1967). The Effect of Performance on Job Satisfaction. Industrial Relations: A Journal of Economy and Society, 7(1), 20-28. doi:10.1111/j.1468-232X.1967.tb01060.x

86. Lee, C. \& Way, K. (2010). Individual Employment Characteristics of Hotel Employees that Play a Role in Employee Satisfaction and Work Retention. International Journal of Hospitality Management, 29(3), 344-353. doi:10.1016/j.ijhm.2009.08.008

87. Lee-Ross, D. (1998). A Practical Theory of Motivation Applied to Hotels. International Journal of Contemporary Hospitality Management, 10(2), 68-74. doi:10.1108/09596119810207219

88. Liu, Z. \& Yang, J. (2009, December). A Study on Job Satisfaction of Hotel Employees. in 2009 International Conference on Information Management, Innovation Management and Industrial Engineering (pp. 204-209). IEEE. doi:10.1109/ICIII.2009.510

89. Lopopolo, R. B. (2002). The Relationship of Role-Related Variables to Job Satisfaction and Commitment to the Organization in a Restructured Hospital Environment, Physical Therapy, 82(10), 984-999. doi:10.1093/ptj/82.10.984

90. Lu, L., Lu, A. C. C., Gürsoy, D. \& Neale, N. R. (2016). Work Engagement, Job Satisfaction, and Turnover Intentions: A Comparison Between Supervisors and Line-Level Employees. International Journal of Contemporary Hospitality Management, 28(4), 737-761. doi:10.1108/IJCHM-07-2014-0360 


\section{JOURNAL OF TOURISM AND SERVICES}

Issue 20, volume 11, ISSN 1804-5650(Online)

www.jots.cz

91. McNamara, M., Bohle, P. \& Quinlan, M. (2011). Precarious Employment, Working Hours, WorkLife Conflict and Health in Hotel Work. Applied Ergonomics, 42(2), 225-232. doi:10.1016/j.apergo.2010.06.013

92. Mimaroğlu, H. \& Özgen, H. (2008). Örgütlerde Güç Eşitsizlikleri ve Cinsel Taciz. Ç.Ü. Sosyal Bilimler Enstitüsü Dergisi, 17(1), 321-334.

93. Ministry of Culture and Tourism (2019). https://eskisehir.ktb.gov.tr/TR-158499/turizmisletmesi-belgeli-oteller.html, (accessed in March 28, 2019).

94. Mulyani S. R., Sari V. N. \& Sari M. W. (2019) The Model of Employee Motivation and Cooperative Employee Performance. Polish Journal of Management Studies, 20(2), 379-390. doi:10.17512/pjms.2019.20.2.32

95. Mura, L., Gontkovicova, B., Dulova Spisakova, E., \& Hajduova, Z. (2019). Position of Employee Benefits in Remuneration Structure. Transformations in Business and Economics, 182 (47), 156-173

96. Näswall, K., Sverke, M. \& Hellgren, J. (2005). The Moderating Role of Personality Characteristics on the Relationship Between Job Insecurity and Strain. Work \& Stress, 19(1), 37-49. doi:10.1080/02678370500057850

97. Oshagbemi, T. (2000). Is Length of Service Related to the Level of Job Satisfaction?. International Journal of Social Economics, 27(3), 213-226. doi:10.1108/03068290010286546

98. Örücü, E. \& Esenkal, F. (2005). Konaklama İşletmelerinde İş Gören Tatminini Etkileyen Faktörler (Bandırma ve ErdekÖrneği). Bahkesir University Journal of Social Sciences Institute, 8(14), 141-166.

99. Özkalp, E. (2015). Duygular, Tutumlar ve İş Tatmini. A. Ç. Kırel \& O. Ağlargöz (Eds.), In Örgütsel Davranıs (pp. 56-8.). Eskişehir: Anadolu Üniversitesi Açıköğretim Fakültesi Yayını.

100. Öztürk, A., Tolga, Y., Şenol, V. \& Günay, O. (2008). Evaluation of Burnout Levels of Health Managers in Kayseri City, Erciyes Medical Journal, 30(2), 92-99.

101. Pan, F. C. (2015). Practical Application of Importance-Performance Analysis in Determining Critical Job Satisfaction Factors of a Tourist Hotel. Tourism Management, 46, 84-91. doi:10.1016/j.tourman.2014.06.004

102. Parasiz, İ. ve Bildirici, M. (2002). Modern Emek Ekonomisi. Bursa: Ezgi Bookstore.

103. Pelit, E., Öztürk, Y. \&Arslantürk, Y. (2011). The Effects of Employee Empowerment on Employee Job Satisfaction: A Study on Hotels in Turkey. International Journal of Contemporary Hospitality Management, 23(6), 784-802.

104. Pryor, J. B. \& Day, J. D. (1988). Interpretations of Sexual Harassment: An Attributional Analysis. Sex Roles, 18(7-8), 405-417.

105. Rhodes, S. R. (1983). Age-Related Differences in Work Attitudes and Behavior: A Review and Conceptual Analysis. Psychological Bulletin, 93(2), 328-367.

106. Rusbult, C. E., Farrell, D., Rogers, G. \& Mainous, A. G. (1988). Impact of Exchange Variables on Exit, Voice, Loyalty, and Neglect: An Integrative Model of Responses to Declining Job Satisfaction. Academy of Management Journal, 31(3), 599-627. doi:0.5465/256461

107. Saari, L. M. \& Judge, T. A. (2004). Employee Attitudes and Job Satisfaction. Human Resource Management: Published in Cooperation with the School of Business Administration, The University of Michigan and in alliancewith the Society of Human Resources Management, 43(4), 395-407. doi:10.1002/hrm.20032

108. Sabuncuoğlu, Z. (1994). Personel Yönetimi. Bursa: Uludağ Üniversitesi Publishing.

109. Sangaran, G. \& Jeetesh, K. (2015). The Effects of Job Satisfaction Towards Employee Turnover in the Hotel Industry: A Case Study of Hotels in Kuala Lumpur City Center. Journal of Tourism \& Hospitality, 4(1), 1-5. doi:10.4172/2167-0269.1000142

110. Seçer, B. (2011). The Impact of Job Insecurity on Inner Resignation and Life Satisfaction. ISGUC The Journal of Industrial Relations and Human Resources, 13(4), 43-60. doi:10.4026/13032860.2011.0188.x 


\section{JOURNAL OF TOURISM AND SERVICES}

Issue 20, volume 11, ISSN 1804-5650(Online)

www.jots.cz

111. Seymen, O., A. \& Bolat, T. (2005). Örgütlerde Bedensel ve Zihinsel Engelli İş Gören Ayrımcıllŭı: Uygulamalı Etik Boyutuyla Bir Değerlendirme. Marmara Üniversitesi Sosyal Bilimler Enstitüsü Hakemli Dergisi, 23(6), 35-45.

112. Solmuş, T. (2004). İs Yaşamında Duygular ve Kişilerarası Ilişkeiler. İstanbul: Beta Publishing.

113. Solmuş, T. (2005). Traumas in the Worklife: Sexual Harassment and Mobbing. ISGUC The Journal of Industrial Relations and Human Resources, 7(2), 1-14. doi:10.4026/1303-2860.2005.0016.x

114. Şenturan, Ş. (2014). Örnek Olaylarla Örgütsel Davramı̧. İstanbul: Beta Publishing.

115. Şimşek, M., Ş. \& Kıngır, S. (2006). Cağdaş Yönetim Araçlarndan Seçmeler. Ankara: Nobel Publishing. 116. Szczepańska-Woszczyna, K. (2018) Strategy, Corporate Culture, Structure and Operational Processes as the Context for the Innovativeness of an Organization. Foundations of Management, 10 (1), 33-44, doi: 10.2478/fman-2018-0004

117. Taormina, R. J. \& Law, C. M. (2000). Approaches to Preventing Burnout: The Effects of Personal Stress Management and Organizational Socialization. Journal of Nursing Management, 8(2), 89-99. doi:10.1046/j.1365-2834.2000.00156.x

118. Tuncer, M. (2013). Impacts of the Quality of Working Life on the Hotel Employees. Journal of Business Research, 5(1), 57-78.

119. Tutar, H. (2004). İsyerinde Psikolojik Şiddet. Ankara: Platin Publishing.

120. Türk, S. (2007). Örgüt Kültürü ve Iss Tatmini. Ankara: Gazi Publishing.

121. Türkay, O., Korkutata, A. \& Yılmaz, Ö. (2018). Does Animation Services Really Matter? Place of Animation Services in the Perceived Quality-Overall Satisfaction Model. Journal of Tourism and Services, 9(16), 14-30.

122. Tütüncü, O. \& Kozak, M. (2007). An Investigation of Factors Affecting Job Satisfaction. International Journal of Hospitality \& Tourism Administration, 8(1), 1-19. doi:10.1300/J149v08n01_01

123. Uludağ, O., Khan, S. \& Guden, N. (2011). The Effects of Job Satisfaction, Organizational Commitment, Organizational Citizenship Behavior on Turnover Intentions. Hospitality Review, 29(2), 1-2.

124. Üngüren, E. (2008). Organization Conflict Management: A Research on Hospitality Industry. Journal of International Social Research, 1(5), 880-909.

125. Üngüren, E., Cengiz, F. \& Algür, S. (2009). İş Tatmini ve Örgütsel Çatışma Yönetimi Arasındaki İlişkinin Belirlenmesi: Konaklama İşletmeleri Üzerinde Bir Araştırma. Electronic Journal of Social Sciences, 8(27), 36-56.

126. Wharton, A., S., Rotolo, T. \& Bird, S., R. (2000, March). Social Context at Work: A Multilevel Analysis of Job Satisfaction. Sociological Forum, 15(1), 65-90.

127. Wilkinson, W., Podhorska, I., \& Siekelova, A. (2019). Does the Growth of Artificial Intelligence and Automation Shape Talent Attraction and Retention? Psychosociological Issues in Human Resource Management, 7(1), 30-35. doi:10.22381/PIHRM7120192.

128. Vveinhardt, J., \& Gulbovaite, E. (2018). Reliability of methodological and psychometric characteristics of the questionnaire of congruence of personal and organizational values. Oeconomia Copernicana, 9(3), 545-571. doi:10.24136/oc.2018.028.

129. Yalçın, A. \& İplik, F. N. (2007). A Grubu Seyahat Acentalarında Çalışanların Örgütsel Bağllikklarını Etkileyen Faktörlerin Belirlenmesine Yönelik Bir Araştırma: Adana İli Örneği. Selguk University Journal of Social Sciences Institute, (18), 483-500.

130. Yang, J. T. (2010). Antecedents and Consequences of Job Satisfaction in the Hotel Industry. International Journal of Hospitality Management,29(4), 609-619. doi:10.1016/j.ijhm.2009.11.002

131. Yeh, C. M. (2013). Tourism Involvement, Work Engagement and Job Satisfaction Among Frontline Hotel Employees. Annals of Tourism Research, 42, 214-239. doi:10.1016/j.annals.2013.02.002 
132. Yıldırım, C. (2018). Depresyon ve Mesleki Doyumun Işten Ayrılma Niyetine Etkisi. Balıkesir University Social Sciences Institute Department of Tourism Management, Balikesir.

133. Yslmaz, M. ve Sezgin, A. C. (2017). Evaulation of Perception Regarding Job and Occupational Satisfaction of the Kitchen Staff Working at 3, 4, 5-Star Hotels Operating in Konya. Journal of Tourism and Gastronomy Studies, 5(1), 160-171. doi:10.21325/jotags.2017.66

134. Zhang, H., Lam, T. \& Baum, T. (1999). A Study of the InterRelationships Between Employees' Job Satisfaction and Their Demographic Characteristics. Asia Pacific Journal of Tourism Research, 4(2), 49-58. doi:10.1080/10941669908722044

\title{
Brief description of Author/Authors:
}

\author{
Yeliz PEKERŞEN \\ Assistant Professor \\ Faculty of Tourism \\ Gastronomy and Culinary Arts Department \\ Necmettin Erbakan University, Turkey \\ Dere Aşıklar, Köyceğiz Yerleşkesi, Dere Aşıklar Mah, Demeç Sk. No: 42, 42005, Meram/Konya/Turkey \\ +903323251147 \\ yeliz.ulusan@gmail.com \\ Yeliz is an assistant professor at the Faculty of Tourism in Necmettin Erbakan University. Her main \\ research areas are sustainable tourism and innovation in tourism.
}

\section{Onur TUGAY}

Social Science Institute

Gastronomy and Culinary Arts Department

Necmettin Erbakan University, Turkey

Dere Aşıklar, Köyceğiz Yerleşkesi, Dere Aşıklar Mah, Demeç Sk. No: 42, 42005, Meram/Konya/Turkey +90 3323251147

onurtugay26@gmail.com

Onur Tugay is a master's degree student at the faculty of tourism in Necmettin Erbakan University. His main research is modern Anatolian cuisine, pastry and bakery, artisan chocolate, ice cream production, world culinary heritage and stories, and the effects of chemical events on cooking. 